\title{
Public inquiry into UK's response to covid-19
}

\author{
A rapid, transparent review is needed before a second wave
}

\author{
Martin McKee professor of European public health ${ }^{1}$, Mike Gill former regional director of public \\ health $^{2}$, Sarah Wollaston former chair of health and social care select committee ${ }^{3}$ \\ ${ }^{1}$ London School of Hygiene and Tropical Medicine, London, UK ; ${ }^{2}$ London, UK ; ${ }^{3}$ Exeter, UK
}

A public inquiry into the UK's response to covid-19 now seems inevitable, with political and public demands for one that can command widespread support. ${ }^{1}$ While a comprehensive inquiry at some point will be essential, the traditional model, as used with Bloody Sunday ${ }^{2}$ or the Iraq war, ${ }^{3}$ takes years. We do not have time. With some of the highest death rates anywhere and clear problems in implementing an effective, joined-up response, the UK needs answers within months, before a second wave develops.

This is already happening to some extent. Parliamentary committees have identified serious problems and will continue to do so. The science is being examined though the peer reviewed process and academic analyses, ${ }^{4}$ including by the Independent Scientific Advisory Group for Emergencies. ${ }^{5}$ But more is needed, drawing on expert insights in areas that have experienced the greatest problems. At least five main areas require scrutiny.

\section{Scrutiny required}

The first is governance. The Brexit process had already exposed the UK's constitutional weaknesses. ${ }^{6}$ The covid-19 response has reinforced those concerns. They include the unfinished devolution agenda: when the prime minister addressed the nation, he failed to point out that his messages applied only to England. ${ }^{7}$ Local government leaders, including the large metropolitan authorities, have been excluded from discussions. ${ }^{8}$ Experience in countries such as Canada or Germany may be relevant.

Although the prime minister's illness did not help, it is not clear that parliament has been able to scrutinise the actions of ministers. There are examples elsewhere that might be emulated, such as the parliamentary committee with an opposition majority that is scrutinising the New Zealand government's covid-19 response. ${ }^{9}$ A rapid inquiry cannot risk getting bogged down in the detailed scientific advice, but it will be crucial to examine how it was used, especially when there was uncertainty, as well as issues around transparency and independence.

The second is procurement of goods and services. A hollowed out civil service has long turned to outsourcing companies, despite their repeated failures. ${ }^{10}$ Companies with little relevant experience have struggled to organise viral testing ${ }^{11}$ or contact tracing. ${ }^{12}$ The task of coordinating activities with existing organisations, such as NHS laboratories or local public health departments, is too complex for their business model. The procurement of products, such as ventilators and protective equipment, has been beset by problems, echoing longstanding problems in the NHS.

The third is coordination of existing structures. The fragmentation created by the 2012 Health and Social Care Act in England has created major barriers to coordination and leadership across the Department of Health and Social Care, the NHS, Public Health England, and local public health departments. ${ }^{4}$ Similarly, the structural disconnect between the NHS and social care in England has contributed substantially to the pandemic's spread. The limited powers of local government, coupled with the absence of regional structures, also pose a problem. It is inexplicable that mayors of metropolitan authorities have been ignored by ministers. ${ }^{8}$

The fourth is the disproportionate burden on ethnic minority populations. Responses must draw on expertise in basic, clinical, and social sciences, with strong representation from the communities affected.

Finally, international collaboration is essential. ${ }^{13}$ The UK's engagement with its European neighbours was chaotic, with unconvincing excuses invoking overlooked emails. The looming crisis of a no deal Brexit, ${ }^{14}$ with shortages of food and medicines that could coincide with a second wave, is clearly a huge concern but is beyond the scope of a covid-19 inquiry. Nevertheless, we need be to seek practical ways to overcome the obstacles that the government seems determined to create concerning the UK's future relationship with the EU.

\section{Five criteria}

This inquiry must meet five key criteria. It must be quick, broad, ambitious, able to command widespread public and stakeholder support, and focus on the most important weaknesses to date. Given the complexity of the issues involved, the need for 
specialist expertise, and for speed, we recommend a series of panels with membership capable of tackling these issues. Each panel would be asked to find workable solutions that do not require primary legislation or major organisational change, both of which can come later. Nor should panels seek to allocate blame.

Each panel should include a range of disciplines and experience, including those on the front line. The need to challenge accepted wisdom argues for the inclusion of members from other countries. Chairs of each panel could form the core of an overall panel working with others to synthesise cross-cutting issues. Achieving public trust will be difficult but essential, given the secrecy around the official Scientific Advisory Group for Emergencies (SAGE).

One possible model might be the Parliamentary Commission on Banking Standards, which was set up in the wake of the Libor (London inter-bank lending rate) scandal. ${ }^{15}$ This was a joint committee of both Houses of Parliament, including several specialist panels with external experts, which was able to rapidly review the causes and make recommendations. Members participated on condition that the government would consider their recommendations seriously, and many were subsequently accepted and taken forward.

This is an ambitious agenda, and it is naive to think that these challenges, many deep seated and highly political, could be dealt with comprehensively before the second wave of covid- 19 . Rather, what we need is measures to be put in place to mitigate the worst aspects of what has proved to be a deeply dysfunctional system of governance and administration. It will be unforgiveable if we fail to prepare for a second wave.
Competing interests: We have read and understood BMJ policy on declaration of interests and declare that MMcK is a member of Independent SAGE.

Provenance and peer review: Not commissioned; not externally peer reviewed.

1 Parker G. Peers demand post-crisis public inquiry 2020. Financial Times 2020 Apr 15. https://www.ft.com/content/b4bc19e4-fc8d-4502-8e2b-d35a583e6b7f

2 Bloody Sunday Inquiry. Report of the Bloody Sunday Inquiry2020. https://www.gov.uk/ government/publications/report-of-the-bloody-sunday-inquiry

3 Iraq Inquiry. The report of the Iraq Inquiry2020. https://www.gov.uk/government/ publications/the-report-of-the-iraq-inquiry

4 Scally G, Jacobson B, Abbasi K. The UK's public health response to covid-19. BMJ 2020;369:m1932. 10.1136/bmj.m1932 32414712

5 Independent SAGE. COVID-19: what are the options for the UK? 2020. http://www. independentsage.org/wp-content/uploads/2020/05/The-Independent-SAGE-Report.pdf

6 Jarman H, Greer SL, McKee M. Brexit is just a symptom: the constitutional weaknesses it reveals have serious consequences for health. J Public Health (Oxf) 2020;2020:fdz180 10.1093/pubmed/fdz180 31927582

7 Mason R. Boris Johnson's lockdown release condemned as divisive, confusing and vague: Guardian 2020 May 10. https://www.theguardian.com/politics/2020/may/10/boris-johnsoncoronavirus-lockdown-shops-schools-june-reopening

8 Helm T. Revolt over easing of coronavirus lockdown spreads as poll slump hits Boris Johnson. Guardian 2020 May 16. https://www.theguardian.com/business/2020/may/16/ revolt-over-easing-lockdown-spreads-as-poll-slump-hits-prime-minister

9 Bridges S. In the absence of parliament we must ensure New Zealand's response to covid-19 is the best it can be. Guardian 2020 Apr 3. https://www.theguardian.com/ commentisfree/2020/apr/03/in-the-absence-of-parliament-we-must-ensure-new-zealandsresponse-to-covid-19-is-the-best-it-can-be

10 Sasse T, Guerin B, Nickson S, etal . Government outsourcing: what has worked and what needs reform? Institute for Government, 2019.

11 Garside J. Concerns over delays and errors at UK drive-in coronavirus test centres. Guardian 2020 Apr 28. https://www.theguardian.com/society/2020/apr/28/concerns-overdelays-and-errors-at-uk-drive-in-coronavirus-test-CENTRES

12 Perraudin F. "No one had any idea": contact tracers lack knowledge about Covid-19 job: Guardian 2020 May 20. https://www.theguardian.com/world/2020/may/20/no-one-hadany-idea-contact-tracers-lack-knowledge-about-covid-19-job

13 Flear M, de Ruijter A, McKee M. Coronavirus shows how UK must act quickly before being shut out of Europe's health protection systems. BMJ 2020;368:m400. 10.1136/bmj.m400 32005657

14 van Schalkwyk MCl, Barlow P, Stuckler D, etal . Assessing the health effects of a "no deal" Brexit. BMJ 2019;366:I5300. 10.1136/bmj.15300 31466943

15 Parliamentary Commission on Banking Standards. https://www.parliament.uk/ bankingstandards

Published by the BMJ Publishing Group Limited. For permission to use (where not already granted under a licence) please go to http://group.bmj.com/group/rights-licensing/ permissions 